TABLE I-Comparison of Patients treated with Co-trimoxazole and those treated with Other Antibiotics. Results expressed as Means \pm S.D.

\begin{tabular}{|c|c|c|c|c|c|c|}
\hline & $\begin{array}{l}\text { No. of } \\
\text { Patients }\end{array}$ & $\begin{array}{c}\text { Day after } \\
\text { Transplantation at } \\
\text { Start of Treatment }\end{array}$ & $\begin{array}{l}\text { Blood Urea } \\
(\mathrm{mg} / 100 \mathrm{ml})\end{array}$ & $\begin{array}{c}\text { Azathioprine } \\
\text { (mg/day) }\end{array}$ & $\begin{array}{c}\text { Prednisone } \\
\text { (mg/day) }\end{array}$ & $\begin{array}{l}\text { W.B.C. at Start of } \\
\text { Treatment } / \mathrm{mm}^{3}\end{array}$ \\
\hline $\begin{array}{l}\text { Co-trimoxazole } \\
\text { Other antibiotics }\end{array}$ & $\begin{array}{l}47 \\
47\end{array}$ & $\begin{array}{l}208 \cdot 9 \pm 239 \cdot 2 \\
203 \cdot 4 \pm 246 \cdot 4\end{array}$ & $\begin{array}{l}78 \cdot 2 \pm 58 \cdot 2 \\
93.0 \pm 69 \cdot 2\end{array}$ & $\begin{array}{l}90.5 \pm 33.0 \\
91.5 \pm 24.6\end{array}$ & $\begin{array}{l}37.0 \pm 36.3 \\
41.5 \pm 46.9\end{array}$ & $\begin{array}{l}8,446 \cdot 8 \pm 2,947 \cdot 4 \\
8,936 \cdot 1 \pm 3,726 \cdot 5\end{array}$ \\
\hline $\mathbf{P}$ & & $>0.9$ & $>0.2$ & $>0.8$ & $>0.6$ & $>0.2$ \\
\hline
\end{tabular}

*Twenty-eight patients had ampicillin, 11 nitrofurantoin, 3 gentamicin, 2 cephaloridine, 2 nalidixic acid, 1 sulphadimidine.

TABLE II-Data on Patients in both Treatment Groups who developed Leucopenia. Results expressed as Means \pm S.D.

\begin{tabular}{|c|c|c|c|c|c|c|c|c|}
\hline & $\begin{array}{c}\text { Incidence } \\
\text { of } \\
\text { Leucopenia }\end{array}$ & $\begin{array}{c}\text { Days after } \\
\text { Transplantation } \\
\text { at Start of } \\
\text { Treatment }\end{array}$ & $\begin{array}{c}\text { Onsei of } \\
\text { Leucopenia } \\
\text { after Start } \\
\text { of } \\
\text { Treatment } \\
\text { (Days) }\end{array}$ & $\begin{array}{c}\text { Duration } \\
\text { of } \\
\text { Leucopenia } \\
\text { (Days) }\end{array}$ & $\begin{array}{c}\text { Blood } \\
\text { Urea } \\
(\mathrm{mg} / 100 \mathrm{ml})\end{array}$ & $\begin{array}{c}\text { Azathioprine } \\
\text { (mg/day) }\end{array}$ & $\begin{array}{l}\text { Prednisone } \\
\text { (mg/day) }\end{array}$ & $\begin{array}{c}\text { W.B.C. at } \\
\text { Start of } \\
\text { Treatment } \\
/ \mathrm{mm}^{3}\end{array}$ \\
\hline $\begin{array}{l}\text { Co-trimoxazole } \\
\text { Other antibiotics }\end{array}$ & $\begin{array}{r}5 / 47(10.6 \%) \\
11 / 47(23.6 \%)\end{array}$ & $\begin{array}{l}79 \cdot 0 \pm 94 \cdot 4 \\
44 \cdot 9 \pm 27 \cdot 7\end{array}$ & $\begin{array}{l}12.4 \pm 4.8 \\
13.8 \pm 7.5\end{array}$ & $\begin{array}{l}12.6 \pm 9.0 \\
12.7 \pm 7.7\end{array}$ & $\begin{array}{l}123.0 \pm 65.9 \\
148.2 \pm 87.5\end{array}$ & $\begin{array}{l}80 \cdot 2 \pm 44 \cdot 3 \\
84 \cdot 1 \pm 28 \cdot 0\end{array}$ & $\begin{array}{l}71 \cdot 0 \pm 75 \cdot 5 \\
80.0 \pm 63.3\end{array}$ & $\begin{array}{l}7,400 \cdot 0 \pm 2,073 \cdot 6 \\
7,454 \cdot 5 \pm 2,252 \cdot 2\end{array}$ \\
\hline $\mathbf{P}$ & $>0.1$ & $>0.4$ & $>0.6$ & $>0.9$ & $>0.5$ & $>0.8$ & $>0.8$ & $>0.9$ \\
\hline
\end{tabular}

TABLE III-Comparison of Patients who developed Leucopenia with those who did not. Results expressed as Means \pm S.D.

\begin{tabular}{|c|c|c|c|c|c|c|}
\hline & $\begin{array}{l}\text { No. of } \\
\text { Patients }\end{array}$ & $\begin{array}{l}\text { Days after } \\
\text { Transplantation at } \\
\text { Start of Treatment }\end{array}$ & $\begin{array}{l}\text { Blood Urea } \\
(\mathrm{mg} / 100 \mathrm{ml})\end{array}$ & $\begin{array}{l}\text { Azathioprine } \\
\text { (mg/day) }\end{array}$ & $\begin{array}{l}\text { Prednisone } \\
\text { (mg/day) }\end{array}$ & $\begin{array}{l}\text { W.B.C. at Start of } \\
\text { Treatment } / \mathrm{mm}^{2}\end{array}$ \\
\hline $\begin{array}{l}\text { Leucopenic patients } \\
\text { Non-leucopenic patients }\end{array}$ & $\begin{array}{l}16 \\
78\end{array}$ & $\begin{array}{c}55 \cdot 6 \pm 56 \cdot 2 \\
239 \cdot 0 \pm 254 \cdot 0\end{array}$ & $\begin{array}{r}140 \cdot 3 \pm 80 \cdot 1 \\
74 \cdot 4 \pm 54 \cdot 2\end{array}$ & $\begin{array}{l}82 \cdot 6 \pm 32 \cdot 4 \\
92 \cdot 7 \pm 28 \cdot 2\end{array}$ & $\begin{array}{l}77.2 \pm 64.9 \\
31.5 \pm 30.5\end{array}$ & $\begin{array}{l}7,437 \cdot 5 \pm 2,128 \cdot 1 \\
8,884 \cdot 6 \pm 3,471 \cdot 5\end{array}$ \\
\hline $\mathbf{P}$ & & $<0.01$ & $<0.01$ & $>0.2$ & $<0.001$ & $>0.1$ \\
\hline
\end{tabular}

leucopenia between the group treated with co-trimoxazole and that treated with other antibiotics. The critical factor was the dosage of azathioprine in relation to the function of the renal transplant. Azathioprine is known to be partly excreted by the kidney (Elion et al., 1972), and the patients who developed a leucopenia had significantly poorer transplant function than those that did not, yet they received a similar dosage of azathioprine.

Further evidence for the argument that it is the azathioprine and neither the co-trimaxazole nor the other antibiotics used that produce the leucopenia is provided by the three patients in the restrospective survey and the five in this trial who developed a leucopenia while receiving co-trimoxazole. In all eight patients the azathioprine was withdrawn while the co-trimoxazole was continued throughout the leucopenia and the recovery from it.
Thus, we have no evidence with which to incriminate the combination of co-trimoxazole and azathioprine as a more potent cause of leucopenia than azathioprine alone.

I thank Mr. A. D. Barnes, Mr. P. Dawson-Edwards, Dr. B. Robinson, and Dr. J. D. Blainey for their help in the preparation of this paper.

\section{References}

Bateman, G. (1973). Lancot, 2, 1153.

Brumfitt, W., and Pursell, R. (1972). British Medical fournal, 2, 673.

Elion, G. B., et al. (1962). Cancer Chemotherapy Reports, No. 16, 197.

Evan, D. I. K., and Tell, R. (1969). British Medical fournal, 1, 578.

Grüneberg, R. N., and Kolbe, R. (1969). British Medical fournal, 1, 545.

Hulme, B., and Reeves, D. S. (1971). British Medical fournal, 3, 610 .

McCarthy, O. R. (1969). British Medical fournal, 3, 113.

Paulley, W. (1970). British Medical fournal, 2, 364

Reeves, D. S., et al. (1969). British Medical fournal, 1, 541. Department of Gastroenterology, Sahlgren's Hospital, University

G. DOTEVALL, M.D., Associate Professor of Gastroenterology

E. GROLL, M.D., Research Associate, (Present address: Sturegatan, 8, Stockholm, Sweden) tion to exclude organic disease the patients were followed up over two treatment periods of four weeks each under either placebo or the active principle, each patient being his own control. The results indicated that the drug had a beneficial effect $(P<0.05)$ provided that it was given for a period of at least three weeks.

\section{Introduction}

The irritable bowel syndrome is one of the most common disorders of the gastrointestinal tract (Kirsner and Palmer, 1958). It presents with a variety of symptoms and usually 
takes a chronic form. The main feature is an alteration of bowel habit, with constipation or diarrhoea or alternate periods of both. There may be abdominal pain, nausea, distension after meals, flatulence, heartburn, and vomiting and the patients may also complain of fatigue, depression, anxiety, insomnia, and other nervous symptoms (British Medical Fournal, 1972). Treatment has most of ten consisted in giving anticholinergic or antispasmodic drugs either alone or with psychotropic drugs. There has been no controlled trial of treatment with a tranquillizer alone. The purpose of the present investigation was to evaluate the clinical effect of a new substance, mepiprazole, which has pronounced tranquillizing properties but no sedative action in therapeutic doses.

Mepiprazole (fig. 1) belongs to a new group of psychotrophic drugs. It has been shown to have a strong tranquillizing effect in mice, rats, cats, rhesus monkeys, mangabeys, and chimpanzees. It inhibits spontaneous as well as induced (including drug-induced) activities and calms aggressive behaviour selectively (Müller-Calgan, 1970). In rats and cats it is a weaker muscle relaxant than diazepam, chlordiazepoxide, or chlorpromazine and has few if any peripheral spasmolytic, histaminolytic, or adrenolytic properties and no peripheral or central anticholinergic action (Müller-Calgan, 1971). Neuroleptic effects are seen only with doses in the higher range.

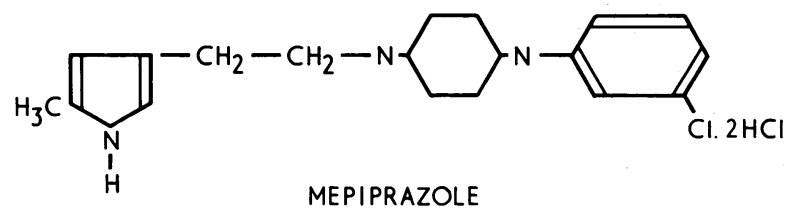

FIG. 1-Formula of mepiprazole.

\section{Patients and Methods}

Twenty-two patients with the irritable bowel syndrome attending a gastroenterological clinic during a period of eight months in 1972-3 were chosen for the trial. Their mean age was 40 years (range 22-68 years) and 11 were women and 11 were men. The duration of their symptoms varied from two to 30 years, with a mean of seven years. The diagnosis was made on the medical history and by excluding by investigations any demonstrable organic disease to which the symptoms could be attributed.

The trial was designed as a double-blind cross-over study of mepiprazole versus placebo. Identical capsules containing either placebo or $5 \mathrm{mg}$ of the active substance were provided by the manufacturer. Each patient was given a four-week supply of capsules. The packages were codified. The patients were randomly assigned to one of two groups, one of which started with the placebo and the other with mepiprazole (fig. 2). After two weeks the patients were seen and questioned about possible side effects and the severity of target symptoms. Symptoms were rated at a score of 0 if unchanged and changes for the better or worse were scored at minus or plus 1 to 3 . At the end of the four-week period the patients were reassessed clinically and the state of the target symptoms and of possible side effects was again checked. There after they received the corresponding cross-over package of capsules. During and after the second period of the trial the symptoms were evaluated in the same way as during the first period (fig. 2). For statistical evaluation the matched pairs signed ranks test according to Wilcoxon was used (Siegel, 1956).

\section{Results}

Nineteen patients completed the trial. Three (two women aged 68 and 48 years and a man aged 30), all of whom were on the active drug, withdrew-one because of vertigo induced by the drug; another because of tachycardia not obviously due to medication; and the third because of prostatitis, very unlikely to have been caused by the drug.

Of those patients who completed the trial mild side effects were noted in four when on active treatment. Two of them complained of headaches, and vertigo, nausea, and increasing irritability were also reported. Three patients on placebo also complained of side effects (one of tachycardia, one of vertigo, and one of nausea).

The 19 patients who completed the trial showed an almost identical response to placebo and the active drug during the first week (fig. 3, table). After two weeks, however, the placebo group did not show any further response whereas the

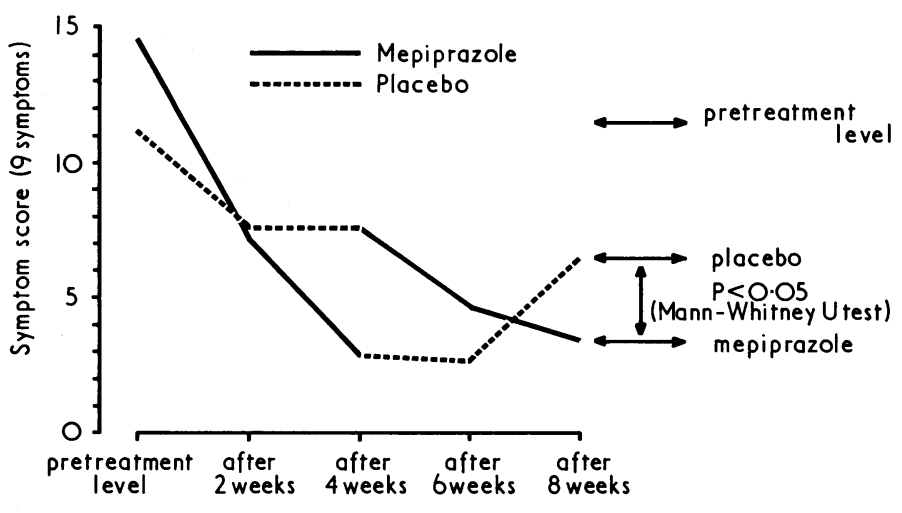

FIG. 3-Mean total symptom scores in double-blind cross-over trial of mepiprazole versus placebo.
FIG. 2-Flow sheet of crossover trial of mepiprazole versus placebo.

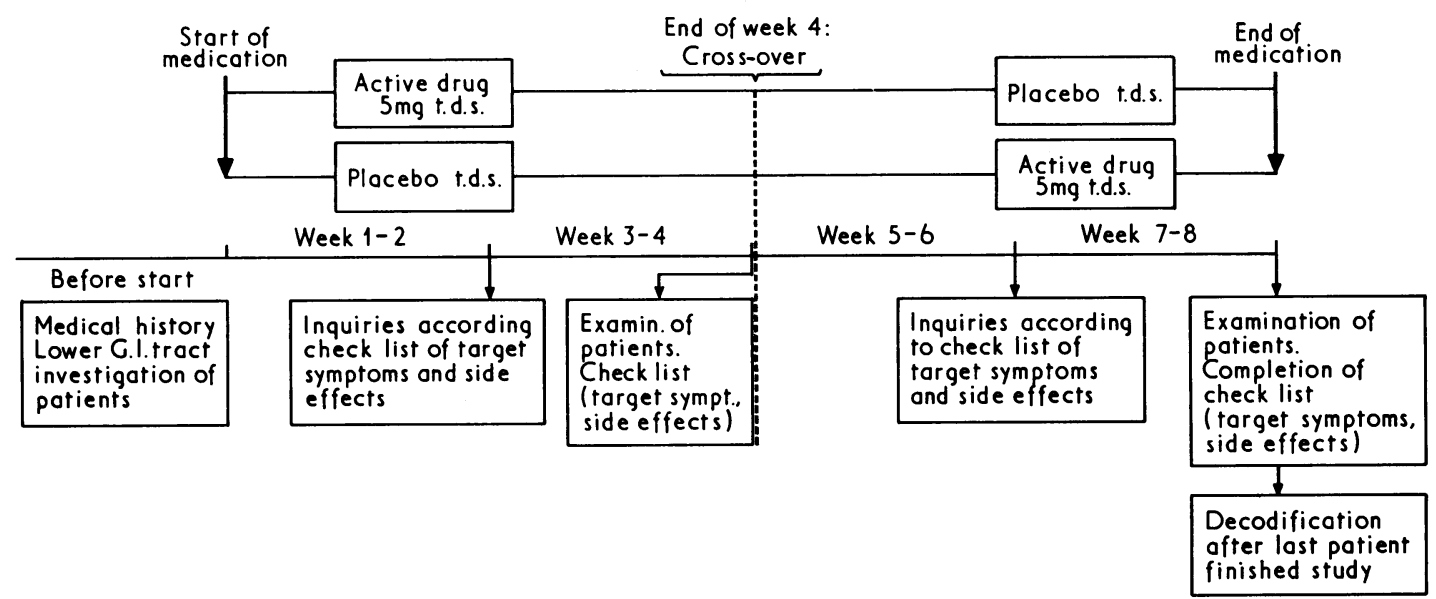


Mean Total Sympton Scores before, during, and after Treatment with Mepiprazole and Placebn

\begin{tabular}{|c|c|c|c|c|}
\hline & Agent & Group 1 & Agent & Group 2 \\
\hline $\begin{array}{l}\text { Pretreatment } \\
\text { After } 2 \text { weekss } \\
\text { " }\end{array}$ & Placebo & $\begin{array}{c}11 \cdot 17 \\
7 \cdot 5 \\
7 \cdot 5\end{array}$ & Mepiprazole \{ & $\begin{array}{c}13 \cdot 67 \\
7 \cdot 25 \\
3 \cdot 0\end{array}$ \\
\hline $\begin{array}{lll} & 6 & 6\end{array}$ & Mepiprazole \{ & $\begin{array}{l}5 \cdot 0 \\
3 \cdot 5\end{array}$ & Placebo \{ & $\begin{array}{l}2 \cdot 75 \\
6 \cdot 5\end{array}$ \\
\hline
\end{tabular}

active group continued to improve. In those who switched at four weeks from the active to the placebo group there was at first a "steady state" of symptoms. After further medication with placebo the total score for the target symptoms sharply increased (fig. 3). In those who switched from the placebo to the active group at four weeks there was a continuous drop in the score rating for target symptoms until the end of the trial (fig. 3). The difference between the placebo group and the active group was statistically significant $(P<0.05)$

\section{Discussion}

The results of this trial of a tranquillizing agent alone in the treatment of the irritable bowel syndrome could lead to a different view of the aetiology of this disorder. When higher centres in the brain supersede the autonomic system in the regulation of the gut (Wolf, 1967) emotional disturbances may well affect the normal functioning of the lower bowel. Domestic or financial stress, occupational worries, and marital difficulties are common findings in the history of the syndrome (Chaudhary and Truelove, 1962). Treatment with a tranquillizer like mepiprazole which inhibits aggression and acts on certain monoaminergic systems might therefore be expected to be helpful (Fuxe, 1974). Nevertheless, tranquillizers do not abolish the cause of the stress and the patient should also be offered all possible support to try to overcome the psychosocial factors.

When gastroenterological symptoms are present disturbed autonomic function is clear-cut evidence of an extension of a primarily psychic irritation to the psychosomatic level. Thus the use of tranquillizing drugs seems to be justified. In the first two weeks of the present study the effect of the active drug did not differ significantly from that of the placebo. When considering the mean duration of the symptoms (seven years) and the psychic aetiology of the disorder a fairly good response to the placebo could be expected. Patients with the irritable bowel syndrome seem to respond to any drug at first, especially if they have confidence in their physician. After two weeks, however, our placebo group remained stationary whereas the group on the active substance continued to improve. After four weeks the difference in response was quite obvious.

The results after the cross-over at four weeks confirmed the findings in the first four weeks. The initial placebo group showed the same improvement as did the group which began with mepiprazole. That the symptoms of the patients who had received the active drug first did not start to get worse until after a fortnight could have been due to a carryover effect. That their symptoms worsened in the second half of the placebo period is evidence that the placebo was ineffective compared with mepiprazole. It also indicates that the irritable bowel syndrome is a chronic condition which can be helped but not cured by treatment. Patients with the disorder require treatment over a long period.

In our opinion further studies are needed to evaluate the place of psychotropic drugs in the treatment of functional disorders of the gut. The present study shows that they relieve the symptoms of the irritable bowel syndrome.

We thank E. Merck, Darmstadt, who provided the capsules of mepiprazole and placebo.

\section{References}

British Medical fournal, 1972, 1, 197.

Chaudhary, N. A., and Truelove, S. C., (1962). Quarterly fournal of Medicine, $31,307$.

Fuxe, K. (1974). Personal communication. To be published.

Kirsner, J. B., and Palmer, W. L. (1958). Gastroenterclogy, 34, 491.

Müller-Calgan, H. (1970). In Proceedings of 7th Congress Collegium Internationale Neuro-Psychopharmacologicum (C.I.N.P.), Prague.

Müller-Calgan, H. (1971). In Proceedings of $5 \mathrm{th} W$ Wrld Congress on Psychiatry, Mexico City.

Siegel, S. (1951). Nonparametric Statistics for the Behavioral Sciences. New York, McGraw-Hill.

Wolf, S. (1967). Gastroenterology, 52, 288.

\title{
Prevention of Exercise-induced Asthma by Indoramin
}

\author{
S. BIANCO, J. P. GRIFFIN, P. L. KAMBUROFF, F. J. PRIME
}

British Medical fournal, 1974, 4, 18-20

\section{Summary \\ Indoramin, an alpha-adrenoceptor blocking drug, has been found to prevent the occurrence of exercise-induced bronchoconstriction. Evidence is provided in two cases that this was not due to the antihistamine properties of indoramin.}

Respiratory Physiology Laboratories Department of Medicine, Respiratory Physiology Laboratories Depa

S. BIANCO, M.D., Professor (Present address: Instituto di Clinica Tisologica, Milano)

J. P. GRIFFIN, M.B., PH.D., Honorary Research Assistant

P. L. KAMBUROFF, M.SC., PH.D.

F. J. PRIME, M.D., F.R.C.P., Senior Lecturer, Reader in Applied Physiology

\section{Introduction}

We have been interested in the possible application of alphaadrenergic blocking drugs in the treatment of asthma after we found evidence of the existence of these receptors in the human bronchial tree (Prime et al., 1972). We investigated the effects of a relatively new alpha-blocking drug, indoramin, on exerciseinduced asthma in 11 patients who showed the typical phenomena of this disorder.

Indoramin is an alpha-adrenergic blocking agent (fig. 1). Its pharmacology has been reported in detail by Alps et al. (1970 a, b, c). Clinically, indoramin has been studied as an antihypertensive agent (Lewis et al., 1973). One property of this drug which made it of particular interest for our studies in the treatment of asthma was the fact that it has been shown to be concentrated in the lung (Johnson, 1974). In addition to its alpha-blocking action it is also an antihistamine and antagonizes serotonin. 